\title{
Climate-induced range shifts of the American jackknife clam Ensis directus in Europe
}

\author{
V. Raybaud • G. Beaugrand · J.-M. Dewarumez • \\ C. Luczak
}

Received: 4 December 2013/Accepted: 6 August 2014/Published online: 13 September 2014

(C) The Author(s) 2014. This article is published with open access at Springerlink.com

\begin{abstract}
Mapping the future potential distribution of alien species has become an issue of great concern. Ecological niche models are increasingly used to forecast the spatial range of introduced species in the context of climate warming. Here, we studied the potential spread of the American jackknife clam Ensis directus into European waters. E. directus, a marine bivalve native to the American coasts, was observed in Europe for the first time in the German Bight at the end of the 1970s. Afterwards, the clam quickly colonized the surrounding waters of the North Sea. Although many studies focused on its biology, ecology and colonization, the extent to which $E$. directus may invade European and Nordic seas remained poorly known. In this study, we used two ecological niche models (ENMs), calibrated on the native area of the
\end{abstract}

V. Raybaud $(\bowtie) \cdot$ G. Beaugrand · J.-M. Dewarumez

UMR 8187 LOG, Laboratoire d'Océanologie et de

Géosciences, Université Lille 1 - Sciences et

Technologies (USTL), 28 Avenue Foch,

62930 Wimereux, France

e-mail: virginie.raybaud@univ-lille1.fr

V. Raybaud · G. Beaugrand · J.-M. Dewarumez ·

C. Luczak

UMR 8187 LOG, Laboratoire d'Océanologie et de

Géosciences, CNRS, 28 Avenue Foch, 62930 Wimereux,

France

C. Luczak

IUFM, Centre de Gravelines, Université d'Artois, 40 rue

V. Hugo - BP 129, 59820 Gravelines, France mollusk, to evaluate the potential distributional range of the bivalve over European seas. Under current environmental conditions, E. directus should continue to progress towards the southern coasts of France and may also invade new areas in the Adriatic Sea. Projections for the end of the century suggest that the probability of occurrence of $E$. directus increases from Denmark to France with both ENMs. The Tunisian coasts may also become a new suitable area for the mollusk but the results of the two ENMs differ for this region. Therefore, contrary to what is often observed, a southward range expansion of $E$. directus is probable, especially as climate will get warmer.

Keywords American jackknife - Ensis directus . Ecological niche model . Thermal preference . Climate change $\cdot$ Geographical distribution

\section{Introduction}

The accidental introduction of terrestrial and marine non-indigenous species by human activities is occurring throughout the world and mapping their future potential distribution in the context of climate warming has become an issue of great concern. In the oceans, several human activities form pathways for the introduction of alien species such as ballast waters, fouling of ships, aquaculture trade, aquariums escape and canal construction. Due to an intense maritime 
transport, the North Sea is one of the marine ecoregions the most affected by alien species (Molnar et al. 2008). In this region, a peak of newcomers was observed in the 1970s.

Among them, the American jackknife clam Ensis directus (syn. Ensis americanus), a bivalve native to the North American Atlantic coasts, was observed in Europe for the first time in the German Bight in June 1979, probably transported during its larval stage by ballast waters (Von Cosel et al. 1982). The mollusk subsequently colonized rapidly the surrounding German coasts (Von Cosel et al. 1982; MühlenhardtSiegel et al. 1983; Swennen et al. 1985), reached Denmark and Netherlands in 1982, Belgium in 1986 and France in 1991 (Luczak et al. 1993). The American jackknife clam was also observed along several coastlines in England (Von Cosel 2009), in south Wales (Vierna et al. 2012) and in the Cantabrian Sea (Arias and Anadón 2012). The dispersal of $E$. directus is facilitated by an actaeplanic free-swimming larval stage (between 2 and 4 weeks), which allows the species to reach a distance up to $125 \mathrm{~km}$ from the source population (Armonies 2001). In the region where $E$. directus was introduced, the overall residual current flows from southwest to northeast (Bailly du Bois and Dumas 2005). Unexpectedly, the direction of colonization of E. directus after its introduction in the German Bight was not only oriented towards the northeast but also towards the southeast in the direction of the French coasts (Luczak et al. 1993). Wind conditions explained this transport of meroplankton in the opposite direction to the prevailing northeasterly residual tidal current, allowing for a southwesterly dispersal (Belgrano et al. 1995). E. directus, usually embedded in patches and dense populations, can alter the structure of the sediment. In the regions where E. directus was introduced, interspecific competition with their native counterparts occurs for food and space. The species presents frequent mass mortality events (Vierna et al. 2012; Cadée et al. 1994) during which dead razor clams accumulate on beaches and become an important source of food for seabirds (Freudendahl et al. 2010; Tulp et al. 2010). The decomposition of organisms has a negative effect on tourism (odors and sharp shells on the sand) and can damage fishermen's trawls (Dewarumez et al. 2011).

Anticipating how the geographical distribution of an introduced species may change has become an issue of great concern for biodiversity monitoring and ecosystem management. Among the various tools used in conservation planning to protect biodiversity, ENMs provide a way to identify the potential habitat of an invasive species in an ecoregion at equilibrium and their applications have increased exponentially (Barbosa et al. 2012; Pyron et al. 2008; Ficetola et al. 2007). ENMs are based on the concept of the "ecological niche" (sensu Hutchinson, (Hutchinson 1957)), which can be defined as the sum of the environmental factors that a species needs for its survival and reproduction. When applied to introduced species, all ENMs are based on the assumption of niche conservatism and rarely consider biotic interactions such as predation, competition and mutualism (Barbet-Massin and Jiguet 2011; Elith and Leathwick 2009; Guisan and Thuiller 2005; Beaugrand et al. 2013). Moreover, these techniques are based on observed occurrence or abundance data and therefore estimate the realized niche or the potential niche (i.e. the realized niche assessed from a reduced number of ecological dimensions).

In the present study, we applied two recently developed Ecological Niche/Species Distribution Models adapted to presence-only records to model the spatial distribution at equilibrium of $E$. directus in Europe based on environmental factors encountered in its native region (North America). We evaluated the range of the potential suitable habitat of the clam by the end of the twenty-first century using new IPCC Representative Concentration Pathways (RCP) scenarios and five different Atmosphere-Ocean General Circulation Models (AOGCMs) (Moss et al. 2010).

\section{Materials and methods}

Data

\section{Occurrence data of Ensis directus}

In this study, we used 2083 presence data in the native range of the American jackknife clam (North America) and 523 in its introduced area (Europe). These data came from two databases: OBIS (http://www. iobis.org/) and GBIF (http://data.gbif.org/) and the following literature: (Luczak et al. 1993; Dauvin et al. 2007; Cardoso et al. 2011; Gollasch et al. 1999; Drake 2009). We completed the distribution of the clam with National Museum of Wales data from the "Marine 
Bivalves of the British Isles webpage" (http:// naturalhistory.museumwales.ac.uk/britishbivalves/ browserecord.php?-recid=237).

\section{Environmental data}

We used Sea Surface Temperature (SST) data from 1982 to 2009 retrieved from NOAA 4-km Advanced Very High Resolution Radiometer (AVHRR) Pathfinder (Casey et al. 2010). The "Smith and Sandwell Global Seafloor topography" (Smith and Sandwell 1997) was used for bathymetric data. Sea Surface Salinity (SSS) data were obtained from the Levitus' climatology (Levitus 1982) and completed with ICES database (http://www.ices.dk). The climatology 1998-2010 of surface Chlorophyll $a$ concentration was obtained from Seawifs-9 $\mathrm{km}$ data available on NASA's Giovanni portal (Acker and Leptoukh 2007) (http://gdata1.sci.gsfc.nasa.gov/daac-bin/G3/gui.cgi? instance_id=ocean_month). Unfortunately, as no global database on sediment type exists, we could not take into account this factor in our analyses. As the spatial resolution of the different environmental databases was not equivalent, all environmental data were interpolated linearly on a $0.1^{\circ}$ longitude $\times 0.1^{\circ}$ latitude spatial grid, in a geographical domain ranging from $100^{\circ} \mathrm{W}$ to $50^{\circ} \mathrm{W}$ and from $10^{\circ} \mathrm{N}$ to $50^{\circ} \mathrm{N}$ for the native area (America) and from $18^{\circ} \mathrm{W}$ to $30^{\circ} \mathrm{E}$ and from $30^{\circ} \mathrm{N}$ to $68^{\circ} \mathrm{N}$ for the introduced region (Europe). This fine spatial resolution was used to decrease potential bias that may result from the averaging of bathymetry in larger geographical cells (Beaugrand et al. 2011).

\section{Climate models}

In this study, we utilized modeled SST data from new IPCC Representative Concentration Pathways (RCP) scenarios (Moss et al. 2010) for the period 2090-2099. Five climate models were used (IPSL-CM5A-LR, HadGEM2-ES, NASA- GISS-E2-R, CNRM-CM5 and MPI-ESM-LR), with all available RCP experiments scenarios: RCP2.6, 4.5, 6.0 and 8.5 for three first listed models and RCP 2.6, 4.5 and 8.5 for the two last.

Modeling of the American jackknife clam distribution

Understanding the model-based uncertainty is important in any ENM approach and the use of a multi- model approach is advocate to get more robust forecasts (Araújo and New 2007; Pearson et al. 2006; Elith et al. 2006, 2010). In the present work, we used two modelling techniques, both based on presence-only species records:

- the Non-Parametric Probabilistic Ecological Niche (NPPEN) model (Beaugrand et al. 2011),

- the MAXimum ENTropy (MAXENT) model (Phillips et al. 2006).

MAXENT is a species distribution model based on the maximum-entropy approach (Phillips et al. 2004). This technique has been extensively used and is fully described elsewhere (Elith et al. 2011; Phillips et al. 2004; Phillips et al. 2006; Phillips and Dudík 2008). In the present study, we used MAXENT v3.3.3 with "Auto feature" since the presence records used here is greater than 80 (Syfert et al. 2013; Merow et al. 2013).

As MAXENT, the NPPEN model only requires presence-only data, a considerable advantage in a study that focus on marine environment where absences data cannot be inferred with certainty. NPPEN model is based on a non-parametric procedure and uses the Mahalanobis distance, which is independent of the scales of the descriptors (Legendre and Legendre 1998) and enables correlations between variables to be taken into account (Ibañez 1981; Farber and Kadmon 2003). As NPPEN more recent than MAXENT, we recall here the main calculation steps of this technique. A full description of the model can be found in (Beaugrand et al. 2011) and applications in (Lenoir et al. 2011; Raybaud et al. 2013; Chaalali et al. 2013; Frederiksen et al. 2013).

Firstly, a reference matrix $\left(Z_{m, p}\right)$ of the environmental data corresponding to the occurrence records is built. $m$ is the number of rows representing species occurrence and $p$ the number of columns corresponding to abiotic variables. $Z_{m, p}$ is homogenized as explained by Beaugrand et al. (Beaugrand et al. 2011) to (i) remove as far as possible the inaccurate reporting of occurrence data and (ii) eliminate the potential effect of over- or under-sampling in some regions. Secondly, the Mahalanobis generalized distance between observations and the homogenized reference matrix is calculated:

$$
D_{x, Z}^{2}=(x-\bar{Z})^{\prime} R^{-1}(x-\bar{Z})
$$

With $x$, the vector of length $p$, representing the values of the abiotic variable to be tested; $R_{p, p}$ the correlation 
matrix of $Z_{m, p}$ and $\bar{Z}$ the average environmental conditions inferred from $Z_{m, p}$. Thirdly, the probability of each grid point to belong to the reference matrix is calculated by using a simplified version of the Multiple Response Permutation Procedure (Mielke et al. 1981). This probability $(v)$ is the number of times the simulated distance was found greater or equal than the observed average distance:

$v=\frac{q_{\varepsilon_{s} \geq \varepsilon_{0}}}{n}$

With $\varepsilon_{0}$ the average observed distance, $\varepsilon_{s}$ the recalculated distance after permutation and $n$ the maximum number of permutations.

Finally, the probabilities of occurrence are projected into a geographical space to map the current spatial distribution of E. directus in its both native and introduced areas. To study the projected changes in the distribution of E. directus for the end of the twentyfirst century, we calculated 18 maps of potential species distributions for the end of this century using the latest generation of AOGCMs. We then calculated the coefficient of variation to examine where projections are the most variable.

We used a classical approach for invasive species prediction. Both models (MAXENT and NPPEN) were calibrated on the native region of the clam (North America), where the species is at equilibrium with environmental factors. Projections where then projected into the introduced area (Europe) to evaluate the current and future range of the suitable habitat. MAXENT and NPPEN were applied on six different combinations of environmental variables known to influence the ecology of E. directus (Table 1). As explained in the paragraph "Environmental data", no global database on sediment type exists. So we could not take into account this factor although it is well known that $E$. directus lives in sand or muddy sand in low intertidal and shallow subtidal areas (Beukema and Dekker 1995). Therefore, we here calculated the suitability of the habitat without considering sediment types. We therefore map the potential spatial distribution of the species and caution that the spatial distribution may be altered by sediment type.

The selection of the best combination of environmental factors was achieved by applying the area under curve of the receiver operating characteristic (AUC) method (Swets 1988), a commonly procedure used in ENMs literature. The AUC is a threshold independent measure that allows an assessment of the model performance by given a value ranged between 0 and 1 ( 0.5 for a random model and 1 for a perfect one). We used a cross-validation procedure, as recommended by (Merow et al. 2013) and performed by (Tittensor et al. 2009) by selecting $70 \%$ of data to run the model NPPEN and $30 \%$ to evaluate its performance. The AUC method was first developed for the evaluation of presence-absence models. Afterwards, this test has been adapted to evaluate the models based on presence-only data by replacing absences with pseudo-absences in the background locations (the grid cells without species presence) (Wiley et al. 2003; Philips et al. 2006; Tittensor et al. 2009). The application of the adapted AUC method on presenceonly data models has been debated (Lobo et al. 2008; Hernandez et al. 2006) but with the lack of other valuable alternatives, AUC remains the most used procedure (Merow et al. 2013).

\section{Results}

Modeling of the ecological niche of Ensis directus

The best simulations were obtained using triplet of environmental factors including bathymetry, maximum and minimal annual SSTs $\left(\mathrm{AUC}_{N P P E N}=0.84 \pm 0.08\right.$; $\mathrm{AUC}_{M A X E N T}=0.84 \pm 0.01$, Table 1). This was therefore the triplet of factors that we retained for the rest of the study. The ecological niche of the American jackknife clam modeled with NPPEN and MAXENT are presented in Fig. 1.

With NPPEN, probabilities of occurrence higher than $p=0.05$ were found at bathymetries ranging from 0 to $50 \mathrm{~m}$ (Fig. 1a, b). With MAXENT, this range was slightly larger (between 0 and $67 \mathrm{~m}$, Fig. 1d). Both MAXENT and NPPEN modeled high probabilities of occurrence for minimum annual SSTs between 3 and $18{ }^{\circ} \mathrm{C}$ and maximum annual SSTs between 20 and $26.5^{\circ} \mathrm{C}$ (Fig. 1).

Modeling of the current probability of occurrence of Ensis directus in its native area

The modeled geographical distribution of the American jackknife clam at equilibrium in its native area (North America) is presented in Fig. 2. A nil probability corresponds to regions where environmental 
Table 1 Effects of different combinations of environmental factors on the performance of two ecological niche models (NPPEN and MAXENT), applied on the American jackknife clam Ensis directus

\begin{tabular}{|c|c|c|c|c|c|c|c|c|}
\hline Run & Bathymetry & SSTmean & SSTmin & SSTmax & Salinity & Chl $a$ & AUC (NPPEN) & AUC (MAXENT) \\
\hline 1 & $\mathrm{x}$ & $\mathrm{x}$ & & & & & $0.80 \pm 0.08$ & $0.83 \pm 0.01$ \\
\hline 2 & $\mathrm{x}$ & & $\mathrm{x}$ & $\mathrm{x}$ & & & $0.84 \pm 0.08$ & $0.84 \pm 0.01$ \\
\hline 3 & $\mathrm{x}$ & $\mathrm{x}$ & & & $\mathrm{x}$ & & $0.78 \pm 0.11$ & $0.64 \pm 0.01$ \\
\hline 4 & $\mathrm{x}$ & & $\mathrm{x}$ & $\mathrm{x}$ & $\mathrm{x}$ & & $0.67 \pm 0.09$ & $0.64 \pm 0.01$ \\
\hline 5 & $\mathrm{x}$ & $\mathrm{x}$ & & & & $\mathrm{x}$ & $0.79 \pm 0.09$ & $0.77 \pm 0.01$ \\
\hline 6 & $\mathrm{x}$ & & $\mathrm{x}$ & $\mathrm{x}$ & & $\mathrm{x}$ & $0.81 \pm 0.08$ & $0.75 \pm 0.01$ \\
\hline
\end{tabular}

The performance of the models was assessed with the procedure AUC (mean AUC and standard deviation). SSTmean, SSTmin and SSTmax represent mean, minimum, maximum annual sea surface temperatures, respectively. Chl $a$ represent the surface concentration of Chlorophyll $a$

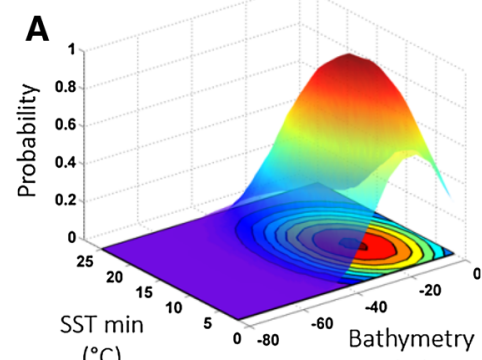

$\left({ }^{\circ} \mathrm{C}\right)$

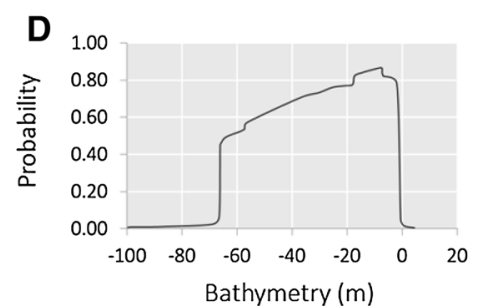

B

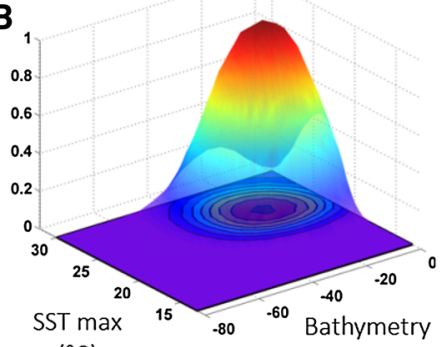

$\left({ }^{\circ} \mathrm{C}\right)$

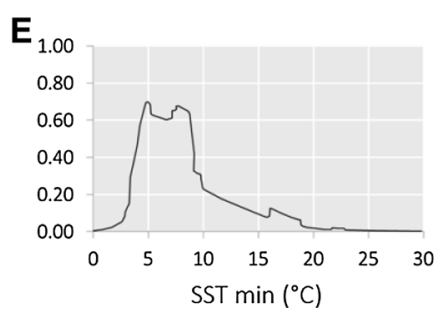

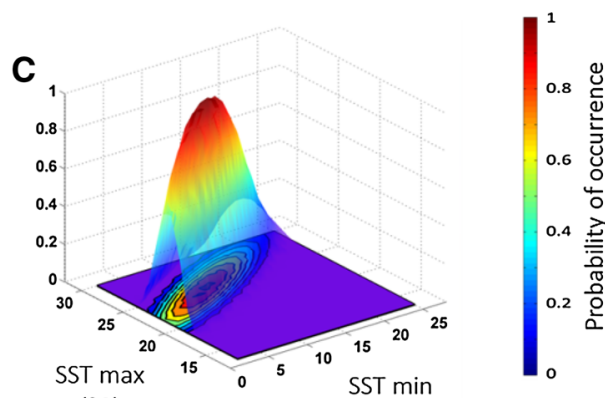

$\left({ }^{\circ} \mathrm{C}\right)$

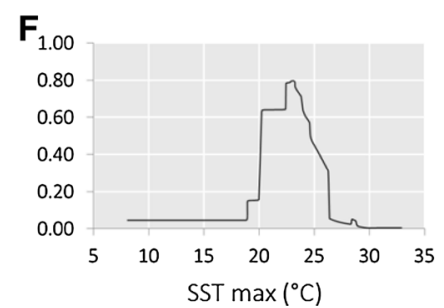

Fig. 1 Ecological niche of the American jackknife clam Ensis directus modeled with the ecological niche models NPPEN (ac) and MAXENT (d-f), based on three environmental

factors are outside the species ecological niche. In contrast, a probability close to 1 denotes a highly suitable environment, providing that the habitat contains sandy sediments. Maps of probabilities of occurrence, modeled by MAXENT and NPPEN, exhibited similar patterns with highest probabilities located from Virginia to Connecticut; a result in agreement with observed records. However, the range of the clam modeled with NPPEN was wider than with MAXENT. In contrast to MAXENT, NPPEN explained the observed occurrence of the clam in the north-eastern part of the Gulf of Mexico (from parameters: minimum annual sea surface temperature (SSTmin), maximum annual sea surface temperature (SSTmax) and bathymetry

Louisiana to Florida) and at the tip of the Yucatan peninsula (Fig. 2). The two occurrence records found in the south-western Gulf of Mexico were not explained by any models.

Modeling of the current probability of occurrence of Ensis directus in its introduced area

Projection of the two modeled ecological niches of $E$. directus (calibrated using the native area) into its introduced region (Europe) allowed the potential species spatial distribution to be represented at 


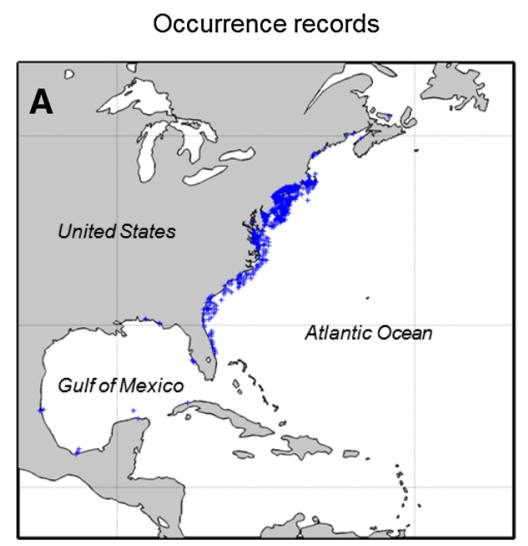

Probability of occurrence (NPPEN)

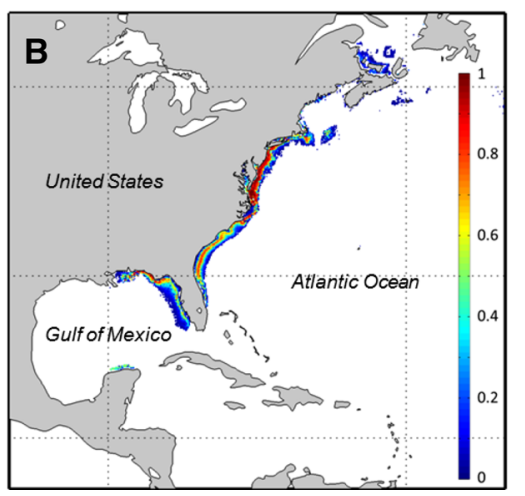

Probability of occurrence (MAXENT)

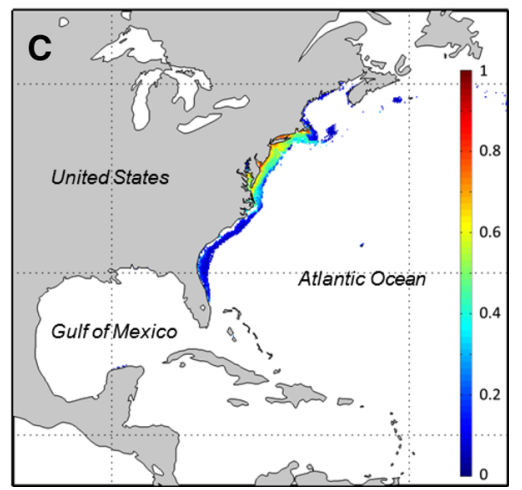

Fig. 2 a Observed occurrence data of the American jackknife clam in its native area (North America); b current probability of occurrence of the mollusk assessed from NPPEN model in the same region; c current probability of occurrence assessed from MAXENT model. In $\mathbf{b}$ and $\mathbf{c}$, white mesh-grid cells denote a nil probability

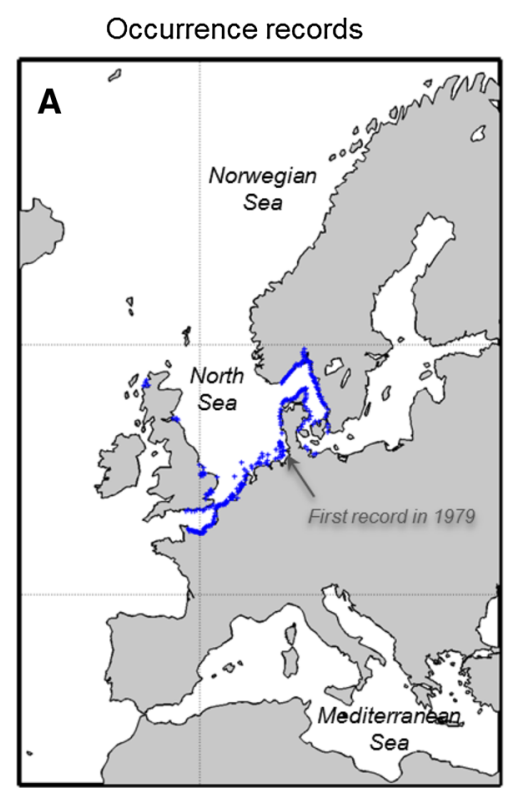

Fig. 3 a Observed occurrence data of the American jackknife clam in its introduced area (Europe); b current probability of occurrence of the mollusk assessed from NPPEN model in the

equilibrium (Fig. 3). Both ENMs (NPPEN and MAXENT) showed a probability of occurrence greater than 0.05 in all regions where the clam has already been observed, with the exception of the southeastern part of Norway (probably caused by the spatial resolution of the bathymetric data). However, the current probability of occurrence modelled with MAXENT in the North Sea and the English Channel was very low $(<0.1)$ in comparison with NPPEN's outputs, where values reach 0.7 . However, since the first record of $E$.

\section{Probability of occurrence (MAXENT)}

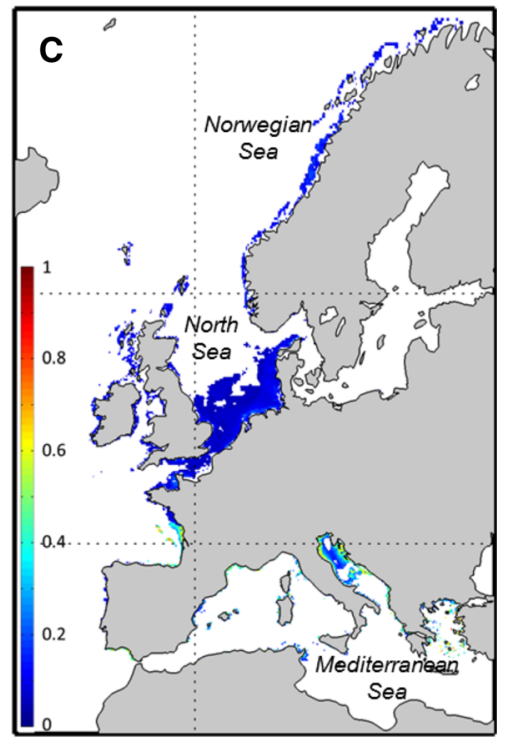

same region; $\mathbf{c}$ current probability of occurrence assessed from MAXENT model. In $\mathbf{b}$ and $\mathbf{c}$, white mesh-grid cells denote a nil probability

directus in Europe in the German Bight in 1979, the clam colonized rapidly the surrounding coasts of the North Sea and the English Channel, suggesting that the clam found a suitable habitat in this area. Therefore, the greater probabilities of occurrence found with NPPEN are more in agreement with the observations than MAXENT's results.

The NPPEN model exhibited the highest probabilities of occurrence from Normandy to the Gironde estuary (Bay of Biscay) in France and in the Adriatic 
Sea. The MAXENT model has the highest values over a small area around the Gironde estuary and along the Adriatic coasts. E. directus has never been observed in these regions, however they present a highly suitable environmental conditions and the habitat contains sandy sediments (Populus et al. 2006; Hamdi et al. 2010).

Potential changes in the geographical range of Ensis directus in Europe by the end of the twenty-first century

Potential changes in the geographical distribution of $E$. directus in its introduced area (Europe) for the end of the twenty-first century were evaluated using five climate models and the most recent set of scenarios (four RCP scenarios), which represent four levels of warming. With the most optimistic scenario (RCP2.6), the potential species distribution modeled by NPPEN was not really modified compared with the current period (Fig. 4a). This result was expected since Scenario RCP2.6 is a "peak-and-decline" scenario: its radiative forcing level first reaches $3.1 \mathrm{~W} / \mathrm{m}^{2}$ by the middle of the century and decrease to $2.6 \mathrm{~W} / \mathrm{m}^{2}$ by 2100 , i.e. below the current value. The probabilities remained relatively low in northern Europe (beyond $60^{\circ} \mathrm{N}$ ), but a slight probability increase was forecasted in the North Sea, from France to Denmark and along the southeastern coast of England. Probabilities of occurrence from Normandy to the Gironde estuary and in the Adriatic Sea remained similar by the end of the twenty-first century. Along Tunisian coasts, a new area appears potentially suitable for the installation of E. directus. As in the Adriatic Sea, if E. directus was accidentally introduced in Tunisia, the species may find suitable environmental conditions towards the end of the century given that muddy-sand sediments are located in this region (Hamdi et al. 2010).

The pattern observed with RCP2.6 was amplified with the two medium scenarios (RCP4.5 and RCP6.0, Fig. 4b, c) and the pessimistic RCP8.5 (Fig. 4d). With the increase of the magnitude of the sea warming, the probability of occurrence became higher in the North Sea and the English Channel and also in the entrance of the Baltic Sea. This result would then strengthen the presence of the species in this area. Beyond $60^{\circ} \mathrm{N}$, the suitability of the habitat remained low by the end of the century whatever the level of warming. Conversely, the probability of occurrence along the
Adriatic coasts was forecasted to stay high for all RCP scenarios. Along Tunisian coasts, the probability of occurrence which was high for the RCP2.6 scenario (Fig. 4a) decreased with the intensity of warming (Fig. 4b, d).

Probabilities estimated by MAXENT were much smaller than those assessed by NPPEN for all scenarios. With Scenario RCP2.6, geographical patterns of probabilities of occurrence modelled by MAXENT were also similar to those calculated for the current period, except for the English Channel where the probabilities were higher (Fig. 5a). As for NPPEN, this result was expected with the "peak-and-decline" scenario RCP2.6. With the three other scenarios (RCP4.5, 6.0 and 8.5), probabilities of occurrence were higher in the entrance of the Baltic Sea, in the North Sea, the English Channel and the Atlantic coasts, from Brittany to the Gironde estuary. These results were similar to those calculated with NPPEN; both ENMs forecasted more suitable habitats for $E$. directus by the end of the century.

The coefficient of variation (CV) calculated for each grid cell using all AOGCMs and RCP scenarios showed the areas where projections varied most from a climate model to another. The CV was calculated both for NPPEN (Fig. 6) and MAXENT (Fig. 7). With NPPEN model, in the areas where the results showed an increase in the probability of occurrence at the end of the century (i.e. in the North Sea, from France to Denmark and along the southeast coast of England), the CVs were low $(<0.4)$ with RCP2.6, 4.5 and 8.5 (Fig. 6a, b, d) and moderate $(<0.6)$ with the medium high RCP6.0 (Fig. 6c). These results indicate that most models agree with an increase of the suitability of the habitats in these regions for the end of the century. In the areas where the species has not been yet observed but where both current and future probabilities of occurrence were high (i.e. from Normandy to the Gironde estuary and in the Adriatic Sea), the CVs were low for all levels of warming, indicating that all models agree that these regions will remain suitable for the establishment and the persistence of the species (Fig. 6a-d). Along the Tunisian coasts, the CVs were also small with all RCP scenarios (between 0 and 0.4 ), although they slightly increased with the magnitude of the warming (i.e. lowest CV with RCP2.6 and highest with RCP8.5), showing a slight divergence pattern in this area with the level of warming (Fig. 6a-d). 

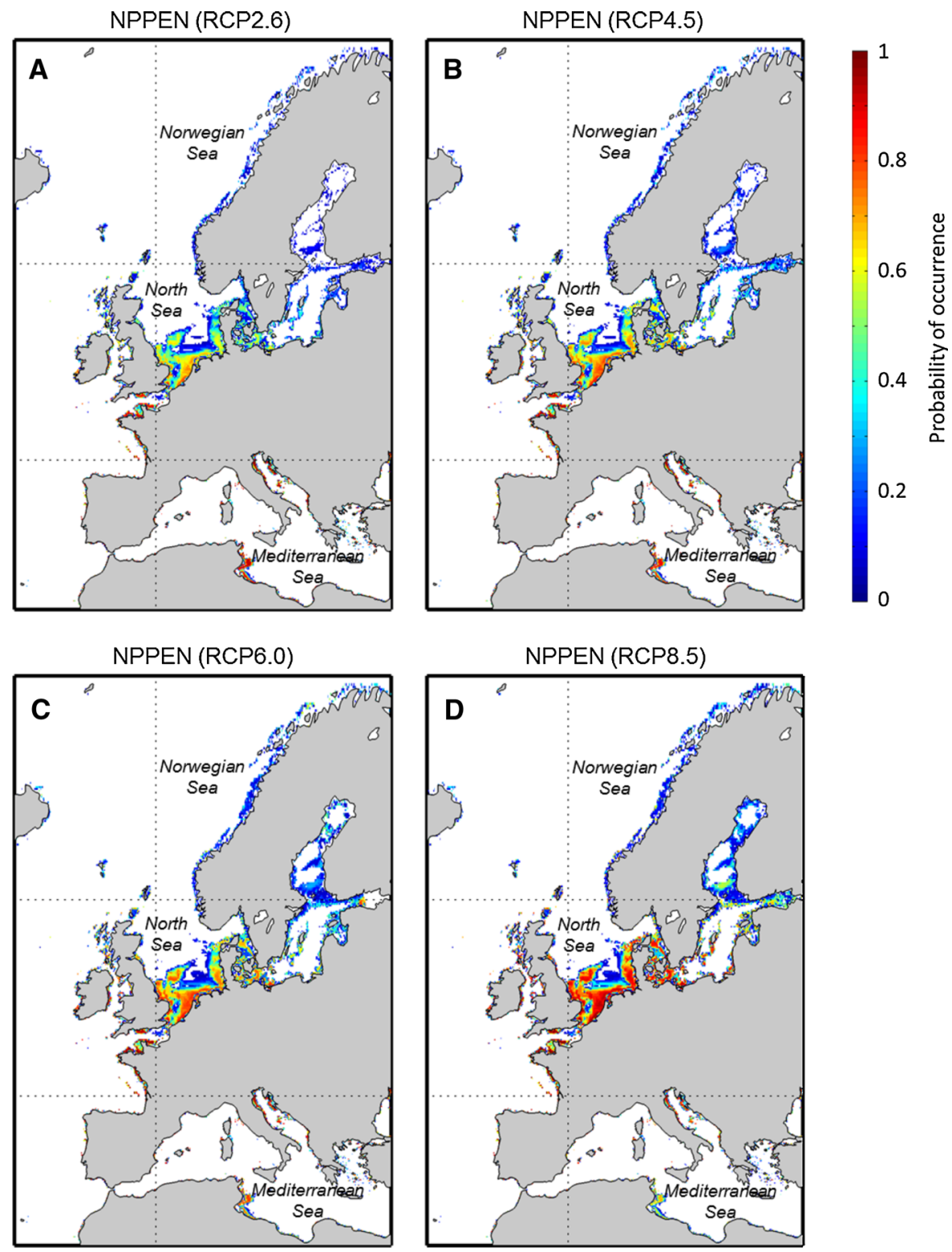

Fig. 4 Projected mean probability of occurrence of E. directus in Europe assessed with the model NPPEN for the period 2090-2099 from five climate models and four RCP scenarios:

CV maps based on MAXENT showed highest values than those calculated from NPPEN. These results can be explained by the examination of the niche modeled by two ENMs (Fig. 1). At the fringe of the ecological niche modeled with MAXENT, the probability of occurrence strongly varies, even for small environmental variations. CV map calculated from Scenarios RCP2.6 exhibits highest values in the English Channel, the southern North Sea and in the a RCP2.6; b RCP4.5; c RCP6.0; d RCP8.5. White mesh-grid cells denote a nil probability. The same maps modeled with MAXENT are presented in Fig. 5

entrance of the Baltic Sea, indicating that some climate models forecasted a suitable habitat for the clam by the end of the century while others did not (Fig. 7a). With scenarios RCP4.5, these areas extended northwards in the North Sea and in the entrance of the Baltic Sea (Fig. 7b). In the Adriatic Sea and along the Tunisian coasts, $\mathrm{CV}$ values also increased in comparison with Scenarios RCP2.6. CV maps based on Scenarios RCP6.0 and 8.5 exhibited 
Fig. 5 Projected mean probability of occurrence of E. directus in Europe assessed with the model MAXENT for the period 2090-2099 from five climate models and four RCP scenarios: a RCP2.6; b RCP4.5; c RCP6.0; d RCP8.5. White mesh-grid cells denote a nil probability. The same maps modeled with NPPEN are presented in Fig. 4
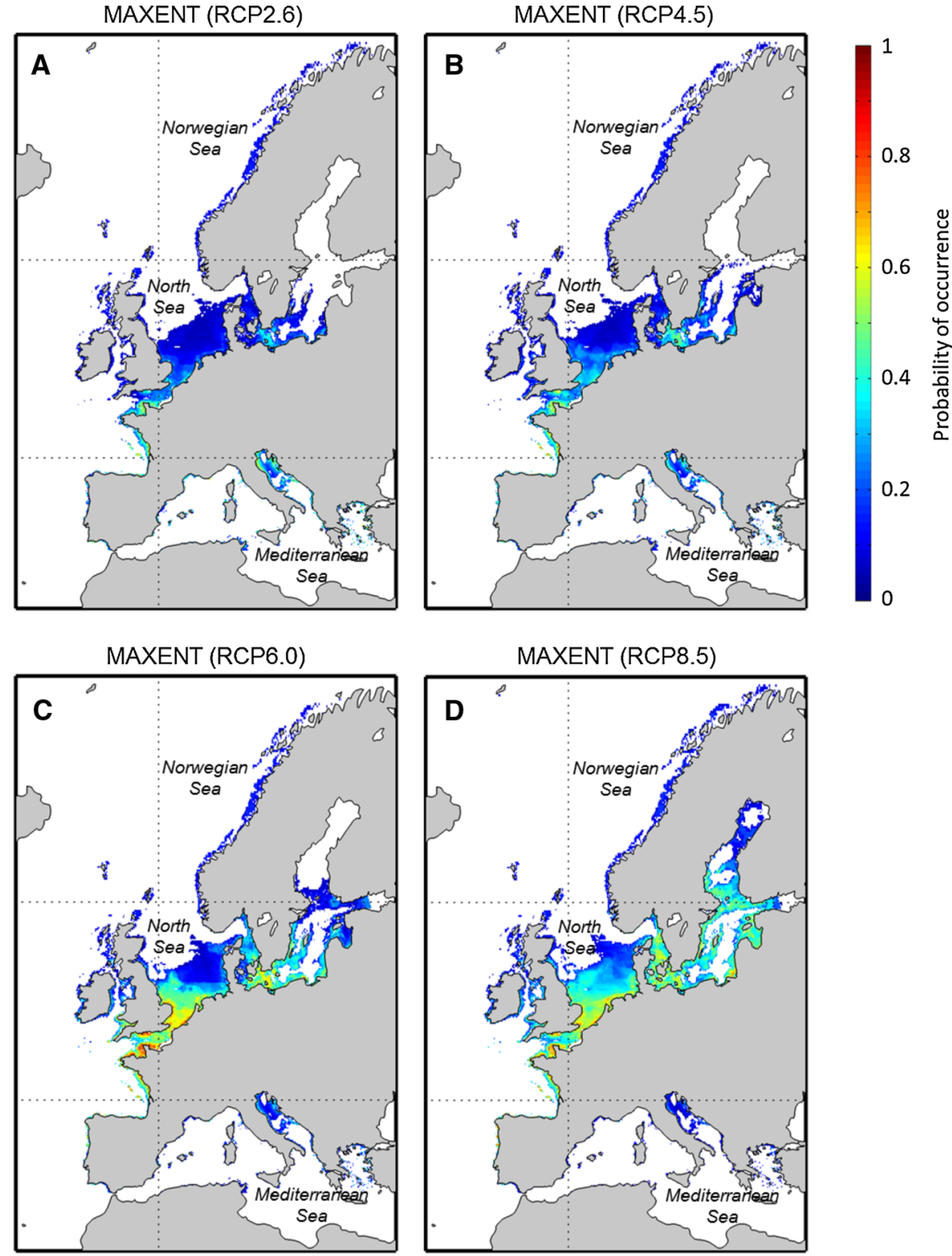

low values along French Atlantic coasts and in the English Channel. Highest CV values were found in the central part of the North Sea, in the Baltic Sea and along Adriatic and Tunisian coasts.

\section{Discussion}

Assumptions and limitations

ENMs are increasingly used in the context of global change but these methods relies on some assumptions and present several potential limitations (Beaugrand et al. 2013; Elith and Leathwick 2009; Peterson 2006; Wiens et al. 2009; Václavík and Meentemeyer 2009). As in any modelling approach, it is important to consider carefully hypothesis behind procedures being used. The first hypotheses made when using ENMs is that species are in equilibrium with their environment (Václavík and Meentemeyer 2012; Araújo and Pearson 2005; Elith et al. 2010). This assumption is easily violated for species with low demographic turn-over and limited dispersal capacities (Pearson and Dawson 2003). This is not the case for the American jackknife 
Fig. 6 Coefficient of variation of the probability of occurrence assessed with the model NPPEN and based on the five climate models and four RCP scenarios: a RCP2.6; b RCP4.5; c RCP6.0; d RCP8.5. The same maps modeled with MAXENT are presented in Fig. 7
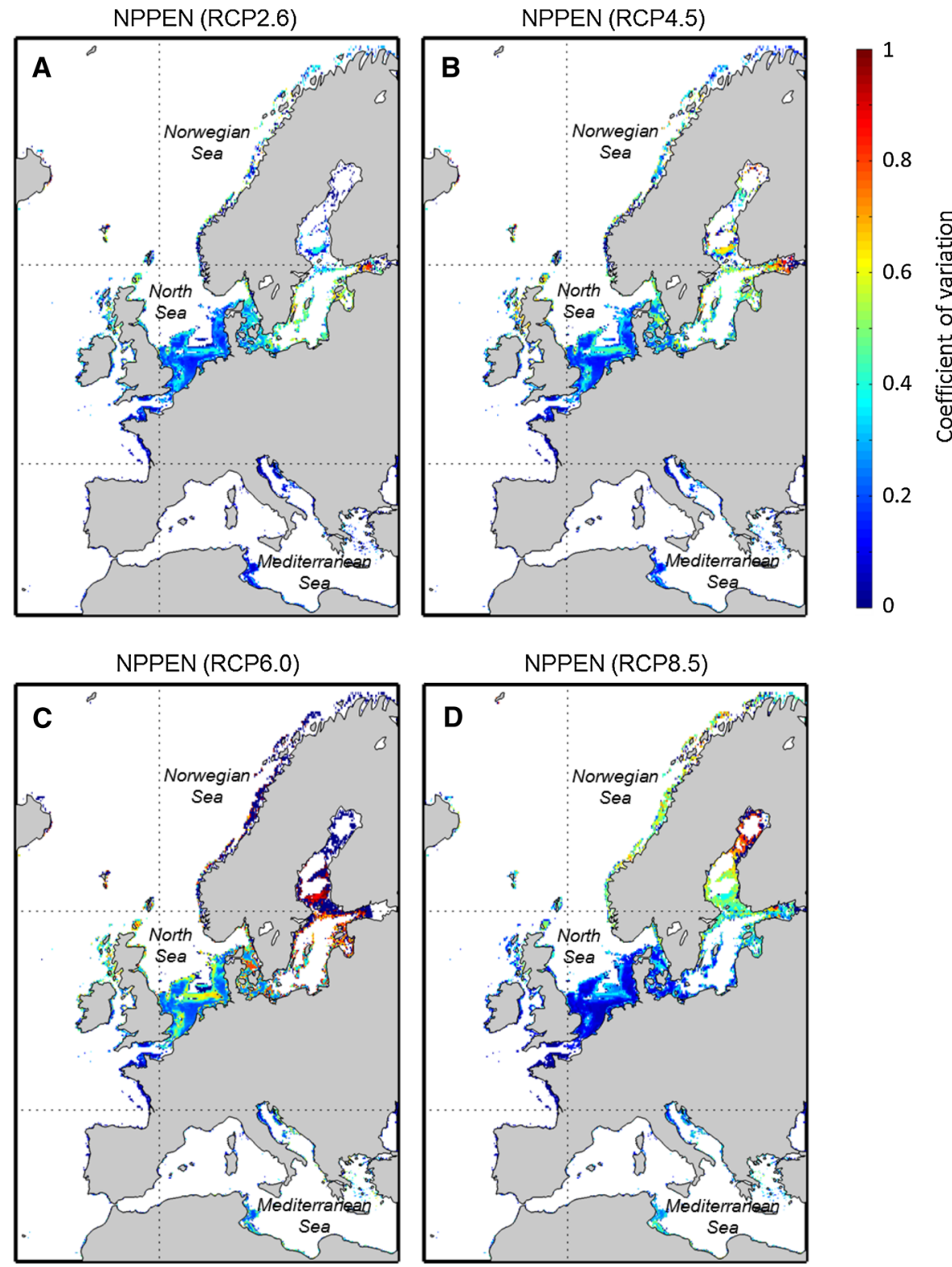

clam. Due to a high reproductive capacity, short generation time and high dispersion capacity during its larval stage (Armonies 2001; Dannheim and Rumohr 2012), E. directus tends to constantly remain in equilibrium with their environment. Moreover, in this study we assessed the ecological niche of E. directus using only occurrence data from its native range (America) and projected it into the introduced area (Europe). This precaution was taken to reduce the risk of violating the assumption of equilibrium since the introduction of the clam in Europe remains relatively recent (Václavík and Meentemeyer 2012).
The second assumption is niche conservatism (Crisp et al. 2009), e.g. the tendency of a species to retain ancestral ecological characteristics (Wiens and Graham 2005). Genetic variations of E. directus in native and introduced sites were recently studied by Vierna and colleagues (Vierna et al. 2012). Against all expectations, they found higher genetic variation at mitochondrial and nuclear markers in the introduced area (Europe) than in its native range (North America). As explained by these authors, a multiple introduction in Europe may explain this genetic variation. However, this interpretation contrasts with the gradual 
Fig. 7 Coefficient of variation of the probability of occurrence assessed with the model MAXENT and based on the five climate models and four RCP scenarios: a RCP2.6; b RCP4.5; c RCP6.0; d RCP8.5. The same maps modeled with NPPEN are presented in Fig. 6
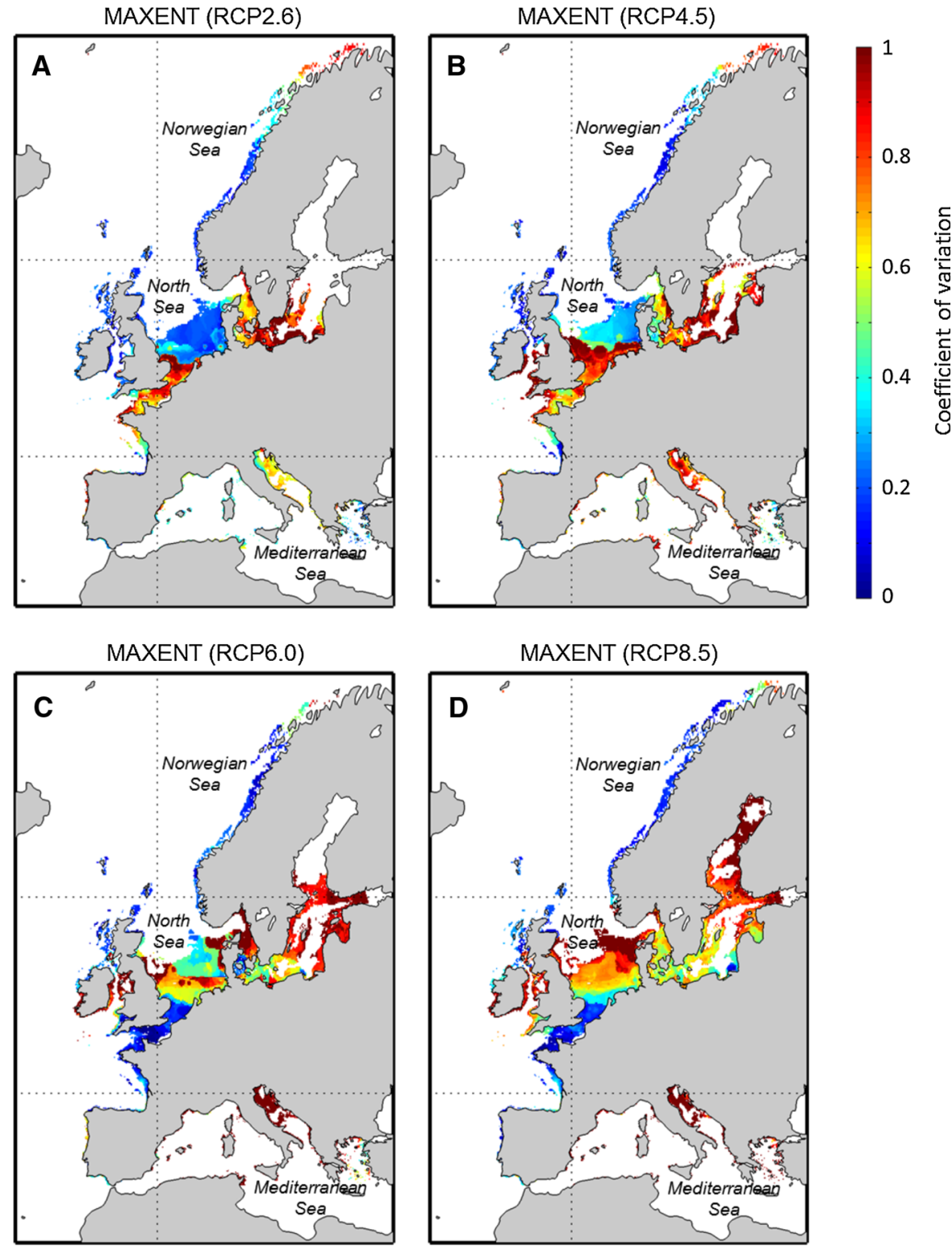

establishment observed along European coasts since 30 years. Niche conservatism and niche shifts are both natural processes: faced with changing environmental conditions, species can adapt (niche shifts) or migrate (niche conservatism) to avoid extinction. The introduction of non-native species may also create opportunities for evolution. Some studies have pointed out a niche differentiation during the invasion process of some species (Broennimann et al. 2007; Fitzpatrick et al. 2007; Gallagher et al. 2010; Medley 2010). However, other studies provided evidence that such results could be caused by methodological flaws (Menke et al. 2009; Feeley and Silman 2011; Rödder et al. 2009).

ENMs also rely on other assumptions. Excluding potential problems related to the correct assessment of the ecological niche (i.e. necessity to have enough occurrence data to characterize the whole ecological niche sensu Hutchinson; (Barry and Elith 2006; Hastie and Fithian 2013)), it is essential to recall that biotic interactions such as predation, competition or trophic interactions are not generally considered in ENMs 
(Barbet-Massin and Jiguet 2011; Elith and Leathwick 2009; Guisan and Thuiller 2005; Raybaud et al. 2011). The hypothesis we made when projecting the spatial distribution of the clam into its invasive area is that species interactions do not differ significantly from its native range. The presence of a strong competitor may alter our projections and the presence of a new predator may also limit the spatial distribution of the American jackknife Clam, especially in the context of species invasions, where novel combinations of species are likely to occur (Elith and Leathwick 2009).

In addition to assumptions and limitations due to the use of ENMs, it is also important to note that our projections of the potential distribution of E. directus under climate change are based on AOGCMs. Although we used the latest generation of climate models (Moss et al. 2010), the uncertainties of these climate models in some regions may alter our results. Nevertheless, in our study, we have applied a multimodel and a multi-scenario approach, as advised by Laepple and colleagues (Laepple et al. 2008), to evaluate the range of possible projections for the end of the twenty-first century.

ENMs are not the only modelling technique to assess the potential spread of an introduced species under climate change. Mechanistic approaches, based on an explicitly representation of physiological processes, incorporate the links between the functional traits of organisms and their environments (Kearney and Porter 2009; Kearney et al. 2010; Kearney 2012). Contrary to ENMs which provides forecasts only in term of probability of presence, mechanistic models offers the ability to predict quantitatively the physiological processes (e.g. levels of growth, reproduction rate) of invasive species (Sarà et al. 2011, 2013b). However, this kind of approach remains scarcely applied because mechanistic models require substantial knowledge on the physiology and life history traits of organisms (Sarà et al. 2013a). The availability of such data for parameters estimation remains often limited to a few species (Václavík and Meentemeyer 2012; Beaugrand et al. 2013). However, ENMs and mechanistic models are complementary approaches and rely on different assumptions. Despite the time required for such a task, future studies should tend to compare predictions derived from different kinds of models applied independently or to couple correlative and mechanistic models (Morin and Thuiller 2009).
Projected equatorward expansion of Ensis directus in Europe

Global warming and introduced species are extensively studied separately but interactions between these two components of global change are more rarely investigated (Stachowicz et al. 2002; Occhipinti-Ambrogi 2007). However, climate change could exacerbate the establishment of non-indigenous species into new regions (Dukes and Mooney 1999). When an exotic species is introduced in an area where the temperature regime corresponds to the colder part of its thermal niche, the progressive increase of temperature related to climate change may boost the establishment and the colonization of the species. This may be the case here for the colonization of the American jackknife clam E. directus into European waters. However, because many stressors act in synergy, the responses of marine ecosystems are likely to be complex and produce surprising outcomes (Occhipinti-Ambrogi 2007). Here, we considered only bioclimatic variables but species interactions may locally favor or impede the expansion of E. directus throughout the European coasts.

Our results suggest that, under the current climate, E. directus may continue its progression southwards until the Gironde estuary. Moreover, if an accidental introduction took place in the Adriatic Sea (through ballast waters for example), the species may potentially find suitable environmental conditions in this region as the habitat also contains sandy sediments (Brambati et al. 1983) but providing that negative species interactions are negligible for this clam. The Tunisian coasts may also become a suitable area for the species towards the end of the century, providing that the species find the sediments suitable for its establishment, condition which is met in this area (Hamdi et al. 2010; Brambati et al. 1983). These conclusions are valid for the two ENMs used in this study. AUC values indicated that the two models show equivalent performances. However, differences were observed on modelled niches and spatial projections. Limits of the ecological niches modelled with both ENMs (minimum and maximum thermal tolerances and bathymetric preference) do not differ greatly and are consistent with the ecological knowledge of the clam (Cardoso et al. 2006, 2009; Dannheim and Rumohr 2012; Dauvin et al. 2007; Dekker and Beukema 2012; Freudendahl et al. 2010; Ghertsos 
et al. 2000; Palmer 2004; Vierna et al. 2012; Beukema and Dekker 1995). The main differences between NPPEN and MAXENT results are generated by the shape of the ecological niche (fringe of the niche steeper with MAXENT than with NPPEN). As a consequence, the map of the current probabilities of occurrence in Europe modelled with NPPEN is more consistent with field observations than the map modelled with MAXENT.

In most studies examining the influence of climate change on species distribution, the authors generally forecast a potential poleward range shift (Beaugrand et al. 2011; Cheung et al. 2013; Lenoir et al. 2011; Parmesan et al. 1999; Raybaud et al. 2013). Here, because $E$. directus was introduced in Europe in the colder part of its thermal niche, our model forecasts an increase in the probability of occurrence in the northern part of Europe but also a possible spread towards the equator during the twenty-first century. Although unusual, equatorward range shifts have already been observed for two reef fish species (Goatley and Bellwood 2014), for the mussel Mytilus galloprovincialis (Hilbish et al. 2010) and for some plants from North America introduced to eastern Asia (Guo et al. 2012). This range shift in the opposite direction that predict global warming remains nevertheless a non-common phenomenon, here induced by the introduction of the clam into the colder part of its suitable area in Europe.

The presence of a new species often modifies the biotic network organization and the overall ecosystem functioning. Therefore, the invasion of E. directus may alter ecosystem structure and functioning. However, beneficial aspects of the introduction of some exotic species have been reported in a few cases. For example, nearly half of the fishes caught near Israeli coasts are some Lessepsian species, which settled in the Mediterranean Sea after the opening of the Suez Canal (Galil and Zenetos 2002). Numerous studies showed that the warming of the Mediterranean Sea facilitated the establishment of Lessepsian species in the Mediterranean Sea (Raitsos et al. 2010; Lejeusne et al. 2010; Boudouresque and Verlaque 2010; Sarà et al. 2013b). No study has reported the disappearance of a native species related to the invasion of E. directus in Europe. Dannheim and colleagues, on the opposite, found that the presence of E. directus favored the settlement of some other deposit feeders (Dannheim and Rumohr 2012). In England, the fishing industry gets interested to harvest the razor clam stocks (the native species E. siliqua and E. arcuatus and the introduced species E. directus) as food source for human consumption (Pyke 2002). In France, aquaculture trials were launched but were economically unprofitable because opportunities for sale remained low. Therefore, if the colonization of E. directus continues through European waters and if the species arrives into new areas as forecasted in this study, beneficial aspects as a commercial species may be limited.

Acknowledgments This work was supported by the "region Nord-Pas de Calais", through the program BIODIMAR (BIODIversity of MARine species), by the ANR programme in the frame of the GlobCoast ANR-11-BLANC-BS56-018_01 project and by the "Centre National de la Recherche Scientifique (CNRS). We acknowledge the World Climate Research Programme's Working Group on Coupled Modeling, which is responsible for CMIP, and we thank the climate modeling groups for producing and making available their model output. For CMIP the U.S. Department of Energy's Program for Climate Model Diagnosis and Intercomparison provides coordinating support and led development of software infrastructure in partnership with the Global Organization for Earth System Science Portals. $4 \mathrm{~km}$ SST-AVHRR data were provided by GHRSST and the US National Oceanographic Data Center. 4 km AVHRR Pathfinder Project was supported in part by a grant from the NOAA Climate Data Record (CDR) Program for satellites.

Open Access This article is distributed under the terms of the Creative Commons Attribution License which permits any use, distribution, and reproduction in any medium, provided the original author(s) and the source are credited.

\section{References}

Acker JG, Leptoukh G (2007) Online analysis enhances use of NASA earth science data. Eos Trans Am Geophys Union 88(2): 14

Araújo MB, New M (2007) Ensemble forecasting of species distributions. Trends Ecol Evol 22(1):42-47

Araújo MB, Pearson RG (2005) Equilibrium of species' distributions with climate. Ecography 28(5):693-695

Arias A, Anadón N (2012) First record of Mercenaria mercenaria (Bivalvia: Veneridae) and Ensis directus (Bivalvia: Pharidae) on Bay of Biscay, Iberian Peninsula. J Shellfish Res 31(1):57-60

Armonies W (2001) What an introduced species can tell us about the spatial extension of benthic populations. Mar Ecol Prog Ser 209:289-294

Bailly du Bois P, Dumas F (2005) Fast hydrodynamic model for medium-and long-term dispersion in seawater in the English Channel and southern North Sea, qualitative and 
quantitative validation by radionuclide tracers. Ocean Model 9(2):169-210

Barbet-Massin M, Jiguet F (2011) Back from a predicted climatic extinction of an island endemic: a future for the corsican nuthatch. PLoS One 6(3):e18228. doi:10.1371/ journal.pone.0018228

Barbosa F, Schneck F, Melo A (2012) Use of ecological niche models to predict the distribution of invasive species: a scientometric analysis. Braz J Biol 72(4):821-829

Barry S, Elith J (2006) Error and uncertainty in habitat models. J Appl Ecol 43(3):413-423

Beaugrand G, Lenoir S, Ibanez F, Manté C (2011) A new model to assess the probability of occurrence of a species based on presence-only data. Mar Ecol Prog Ser 424:175-190. doi:10.3354/MEPS08939

Beaugrand G, Mackas D, Goberville E (2013) Applying the concept of the ecological niche and a macroecological approach to understand how climate influences zooplankton: advantages, assumptions, limitations and requirements. Prog Oceanogr 111:75-90

Belgrano A, Legendre P, Dewarumez J-M, Frontier S (1995) Spatial structure and ecological variation of meroplankton on the French-Belgian coast of the North Sea. Mar Ecol Prog Ser 128:43-50

Beukema J, Dekker R (1995) Dynamics and growth of a recent invader into European coastal waters: the American razor clam, Ensis directus. JMBA-J Mar Biol Assoc U. K. $75(2): 351-362$

Boudouresque CF, Verlaque M (2010) Is global warming involved in the success of seaweed introductions in the Mediterranean Sea? In: Seaweeds and their role in globally changing environments. Springer, Berlin, pp 31-50

Brambati A, Ciabatti M, Fanzutti GP, Marabini F, Marocco R (1983) A new sedimentological and textural map of Northen and central Adriatic Sea. Boll Oceanol Teor Applic 4(1):267-271

Broennimann O, Treier UA, Müller-Schärer H, Thuiller W, Peterson A, Guisan A (2007) Evidence of climatic niche shift during biological invasion. Ecol Lett 10(8):701-709

Cadée G, Cadée-Coenen J, Witte J (1994) Massale sterfte van Ensis directus op Schanserwaard en elders blijft raadselachtig. Corresp Nederlandse Malacol Vereiniging 279:86-93

Cardoso JF, van der Veer HW, Kooijman SA (2006) Body-size scaling relationships in bivalve species: a comparison of field data with predictions by the Dynamic Energy Budget (DEB) theory. J Sea Res 56(2):125-139

Cardoso JF, Witte JI, van der Veer HW (2009) Reproductive investment of the American razor clam Ensis americanus in the Dutch Wadden Sea. J Sea Res 62(4):295-298

Cardoso JFMF, Nieuwland G, Wijsman J, Witbaard R, van der Veer HW (2011) Validation of a method for age determination in the razor clam Ensis directus, with a review on available data on growth, reproduction and physiology. NIOZ-Report: 33 pp

Casey K, Brandon T, Cornillon P, Evans R (2010) The past, present and future of the AVHRR Pathfinder SST program. Oceanography from space: Revisited

Chaalali A, Beaugrand G, Raybaud V, Goberville E, David V, Boët P, Sautour B (2013) Climatic facilitation of the colonization of an Estuary by acartia tonsa. PLoS One 8(9):e74531

Cheung WW, Sarmiento JL, Dunne J, Frölicher TL, Lam VW, Palomares MD, Watson R, Pauly D (2013) Shrinking of fishes exacerbates impacts of global ocean changes on marine ecosystems. Nat Clim Chang 3:254-258

Crisp MD, Arroyo MTK, Cook LG, Gandolfo MA, Jordan GJ, McGlone MS, Weston PH, Westoby M, Wilf P, Linder HP (2009) Phylogenetic biome conservatism on a global scale. Nature 458:754-756

Dannheim J, Rumohr H (2012) The fate of an immigrant: Ensis directus in the eastern German Bight. Helgol Mar Res 66(3):307-317

Dauvin J, Ruellet T, Thiebaut E, Gentil F, Desroy N, Janson A, Duhamel S, Jourde J, Simon S (2007) The presence of Melinna palmata (Annelida: Polychaeta) and Ensis directus (Mollusca: Bivalvia) related to sedimentary changes in the Bay of Seine (English Channel, France). CBM-Cahiers de Biolo Mar 48(4):391-401

Dekker R, Beukema J (2012) Long-term dynamics and productivity of a successful invader: the first three decades of the bivalve Ensis directus in the western Wadden Sea. J Sea Res 71:31-40

Dewarumez J-M, Gévaert F, Massé C, Foveau A, Desroy N, Grulois D (2011) Les espèces marines animales et végétales introduites dans le bassin Artois-Picardie

Drake JA (2009) Handbook of alien species in Europe. DAISIE (Delivering Alien Invasive Species Inventories for Europe), vol 3. Springer, Berlin

Dukes JS, Mooney HA (1999) Does global change increase the success of biological invaders? Trends Ecol Evol 14(4):135-139

Elith J, Leathwick JR (2009) Species distribution models: ecological explanation and prediction across space and time. Annu Rev Ecol Evol Syst 40:677-697

Elith J, Graham CH, Anderson RP, Dudik M, Ferrier S, Guisan A, Hijmans J, Huettmann F, Leathwick JR, Lehmann A, Li J, Lohmann LG, Loiselle BA, Manion G, Moritz C, Nakamura M, Nakazawa Y, Overton JM, Peterson AT, Phillips SJ, Richardson K, Scachetti-Pereira R, Schapire RE, Soberon J, Williams S, Wisz MS, Zimmermann NE (2006) Novel methods improve prediction of species distributions from occurence data. Ecography 29:129-151

Elith J, Kearney M, Phillips S (2010) The art of modelling range-shifting species. Methods Ecol Evol 1(4):330-342

Elith J, Phillips SJ, Hastie T, Dudík M, Chee YE, Yates CJ (2011) A statistical explanation of MaxEnt for ecologists. Divers Distrib 17(1):43-57

Farber O, Kadmon R (2003) Assessment of alternative approaches for bioclimatic modeling with special emphasis on the Mahalanobis distance. Ecol Model 160(1):115-130

Feeley KJ, Silman MR (2011) Keep collecting: accurate species distribution modelling requires more collections than previously thought. Divers Distrib 17(6):1132-1140

Ficetola GF, Thuiller W, Miaud C (2007) Prediction and validation of the potential global distribution of a problematic alien invasive species-the American bullfrog. Divers Distrib 13(4):476-485

Fitzpatrick MC, Weltzin JF, Sanders NJ, Dunn RR (2007) The biogeography of prediction error: why does the introduced 
range of the fire ant over-predict its native range? Glob Ecol Biogeogr 16(1):24-33

Frederiksen M, Anker-Nilssen T, Beaugrand G, Wanless S (2013) Climate, copepods and seabirds in the boreal Northeast Atlantic-current state and future outlook. Glob Change Biol 19(2):364-372

Freudendahl ASL, Nielsen MM, Jensen T, Jensen KT (2010) The introduced clam Ensis americanus in the Wadden Sea: field experiment on impact of bird predation and tidal level on survival and growth. Helgol Mar Res 64(2):93-100

Galil BS, Zenetos A (2002) A sea change: exotics in the Eastern Mediterranean. In: Leppäkoski E, Gollasch S, Olenin S (eds) Invasive aquatic species of Europe: distribution, impacts and management. Kluwer, Dordrecht, pp 325-336

Gallagher RV, Beaumont LJ, Hughes L, Leishman MR (2010) Evidence for climatic niche and biome shifts between native and novel ranges in plant species introduced to Australia. J Ecol 98(4):790-799

Ghertsos K, Luczak C, Dewarumez J-M, Dauvin J-C (2000) Influence of spatial scales of observation on temporal change in diversity and trophic structure of fine-sand communities from the English Channel and the southern North Sea. ICES J Mar Sci J du Conseil 57(5):1481-1487

Goatley CH, Bellwood DR (2014) Moving towards the equator: reverse range shifts in two subtropical reef fish species, Chromis nitida (Pomacentridae) and Pseudolabrus guentheri (Labridae). Mar Biodivers Rec 7:e12

Gollasch S, Minchin D, Rosenthal H, Voigt M (1999) Exotics across the ocean. Case histories on introduced species: their general biology, distribution, range expansion and impact: prepared by Members of the European Union Concerted Action on testing monitoring systems for risk assessment of harmful introductions by ships to European waters (MASCT-97-0111). Department of Fishery Biology, Institute for Marine Science, University of Kiel, Germany

Guisan A, Thuiller W (2005) Predicting species distribution: offering more than simple habitat models. Ecol Lett 8:993-1009

Guo Q, Sax DF, Qian H, Early R (2012) Latitudinal shifts of introduced species: possible causes and implications. Biol Invasions 14(3):547-556

Hamdi A, Vasquez M, Populus J (2010) Cartographie des habitats physiques Eunis-Côtes de France. Convention Ifremer/AAMP n ${ }^{\circ}$ 09/12177764/FY

Hastie T, Fithian W (2013) Inference from presence-only data; the ongoing controversy. Ecography 36:864-867

Hernandez PA, Graham CH, Master LL, Albert DL (2006) The effect of sample size and species characteristics on performance of different species distribution modeling methods. Ecography 29(5):773-785

Hilbish TJ, Brannock PM, Jones KR, Smith AB, Bullock BN, Wethey DS (2010) Historical changes in the distributions of invasive and endemic marine invertebrates are contrary to global warming predictions: the effects of decadal climate oscillations. J Biogeogr 37(3):423-431

Hutchinson GE (1957) Concluding remarks. Cold Spring Harbor Symp Quant Biol 22:415-427

Ibañez F (1981) Immediate detection of heterogeneities in continuous multivariate, oceanographic recordings. Application to time series analysis of changes in the bay of Villefranche sur Mer. Limnol Oceanogr 26:336-349
Kearney M (2012) Metabolic theory, life history and the distribution of a terrestrial ectotherm. Funct Ecol 26(1):167-179

Kearney M, Porter W (2009) Mechanistic niche modelling: combining physiological and spatial data to predict species' ranges. Ecol Lett 12(4):334-350

Kearney M, Simpson SJ, Raubenheimer D, Helmuth B (2010) Modelling the ecological niche from functional traits. Philos Trans Royal Soc B Biol Sci 365(1557):3469-3483

Laepple T, Jewson S, Coughlin K (2008) Interannual temperature predictions using the CMIP3 multi-model ensemble mean. Geophys Res Lett 35(10):L10701. doi:10.1029/ $2008 \mathrm{~g} 1033576$

Legendre P, Legendre L (1998) Numerical ecology, 2nd edn. Elsevier, Amsterdam

Lejeusne C, Chevaldonné P, Pergent-Martini C, Boudouresque CF, Pérez T (2010) Climate change effects on a miniature ocean: the highly diverse, highly impacted Mediterranean Sea. Trends Ecol Evol 25(4):250-260

Lenoir S, Beaugrand G, Lecuyer E (2011) Modelled spatial distribution of marine fish and projected modifications in the North Atlantic Ocean. Glob Chang Biol 17:115-129. doi:10.1111/j.1365-2486.2010.02229.x

Levitus SE (1982) Climatological atlas of the world ocean. NOAA Professional Paper 13. US Government Printing Office, Washington, DC

Lobo JM, Jiménez-Valverde A, Real R (2008) AUC: a misleading measure of the performance of predictive distribution models. Glob Ecol Biogeogr 17(2):145-151

Luczak C, Dewarumez J, Essink K (1993) First record of the American jack knife clam Ensis directus on the French coast of the North Sea. J Mar Biol Assoc U K 73:233-235

Medley KA (2010) Niche shifts during the global invasion of the Asian tiger mosquito, Aedes albopictus Skuse (Culicidae), revealed by reciprocal distribution models. Glob Ecol Biogeogr 19(1):122-133

Menke S, Holway D, Fisher R, Jetz W (2009) Characterizing and predicting species distributions across environments and scales: argentine ant occurrences in the eye of the beholder. Glob Ecol Biogeogr 18(1):50-63

Merow C, Smith MJ, Silander JA (2013) A practical guide to MaxEnt for modeling species' distributions: what it does, and why inputs and settings matter. Ecography 36:1058-1069

Mielke PW, Berry KJ, Brier GW (1981) Application of multiresponse permutation procedures for examining seasonal changes in monthly mean sea-level pressure patterns. Mon Weather Rev 109:120-126

Molnar JL, Gamboa RL, Revenga C, Spalding MD (2008) Assessing the global threat of invasive species to marine biodiversity. Front Ecol Environ 6(9):485-492

Morin X, Thuiller W (2009) Comparing niche-and process-based models to reduce prediction uncertainty in species range shifts under climate change. Ecology 90(5):1301-1313

Moss RH, Edmonds JA, Hibbard KA, Manning MR, Rose SK, van Vuuren DP, Carter TR, Emori S, Kainuma M, Kram T, Meehl GA, Mitchell JFB, Nakicenovic N, Riahi K, Smith SJ, Stouffer RJ, Thomson AM, Weyant JP, Wilbanks TJ (2010) The next generation of scenarios for climate change research and assessment. Nature 463:747-756

Mühlenhardt-Siegel U, Dörjes J, Von Cosel R (1983) Die amerikanische Schwertmuschel Ensis directus (Conrad) in 
der Deutschen Bucht: 2. Populationsdynamik. Senckenbergiana Maritima 15(4-6):93-110

Occhipinti-Ambrogi A (2007) Global change and marine communities: alien species and climate change. Mar Pollut Bull 55(7):342-352

Palmer D (2004) Growth of the razor clam Ensis directus, an alien species in the Wash on the east coast of England. J Mar Biol Assoc U K 84(05):1075-1076

Parmesan C, Ryrholm N, Stefanescu C, Hill JK, Thomas CD, Descimon H, Huntley B, Kaila L, Kullberg J, Tammaru T (1999) Poleward shifts in geographical ranges of butterfly species associated with regional warming. Nature 399(6736):579-583

Pearson RG, Dawson TP (2003) Predicting the impacts of climate change on the distribution of species: are bioclimate envelope models useful? Glob Ecol Biogeogr 12(5):361-371

Pearson RG, Thuiller W, Araújo MB, Martinez-Meyer E, Brotons L, McClean C, Miles L, Segurado P, Dawson TP, Lees DC (2006) Model-based uncertainty in species range prediction. J Biogeogr 33(10):1704-1711

Peterson AT (2006) Uses and requirements of ecological niche models and related distributional models. Biodivers Inf 3:59-72

Philips SJ, Anderson RP, Shapire RE (2006) Maximum entropy modeling of species geographic distributions. Ecol Model 190:231-259

Phillips SJ, Dudík M (2008) Modeling of species distributions with Maxent: new extensions and a comprehensive evaluation. Ecography 31(2):161-175

Phillips SJ, Dudík M, Schapire RE A maximum entropy approach to species distribution modeling. In: Proceedings of the twenty-first international conference on machine learning, 2004. ACM, p 83

Phillips SJ, Anderson RP, Schapire RE (2006) Maximum entropy modeling of species geographic distributions. Ecol Model 190(3):231-259

Populus J, Hamdi A, Golding N, Van Lancker V, De Oliveira E (2006) Towards prediction of seabed habitats. University of Wollongong, Australia

Pyke M (2002) Evaluation of good handling practice for razor clams. Seafish Report No SR548 Sea Fish Industry Authority

Pyron RA, Burbrink FT, Guiher TJ (2008) Claims of potential expansion throughout the US by invasive python species are contradicted by ecological niche models. PLoS One 3(8):e2931

Raitsos DE, Beaugrand G, Georgopoulos D, Zenetos A, Pancucci-Papadopoulou AM, Theocharis A, Papathanassiou E (2010) Global climate change amplifies the entry of tropical species into the Eastern Mediterranean Sea. Limnol Oceanogr 55:1478-1484

Raybaud V, Heroin D, Raud T, Brylinski J-M, Stemmann L, Thibault Botha D, Sautour B (2011) Census and analysis of zooplankton metadata of the French coasts since 1955. J Oceanogr Res Data 4:11-37

Raybaud V, Beaugrand G, Goberville E, Delebecq G, Destombe C, Valero M, Davoult D, Morin P, Gevaert F (2013) Decline in kelp in west Europe and climate. PLoS One 8(6):e66044. doi:10.1371/journal.pone.0066044

Rödder D, Schmidtlein S, Veith M, Lötters S (2009) Alien invasive slider turtle in unpredicted habitat: a matter of niche shift or of predictors studied? PLoS One 4(11):e7843
Sarà G, Kearney M, Helmuth B (2011) Combining heat-transfer and energy budget models to predict thermal stress in mediterranean intertidal mussels. Chem Ecol 27(2):135-145

Sarà G, Palmeri V, Montalto V, Rinaldi A, Widdows J (2013a) Parameterisation of bivalve functional traits for mechanistic eco-physiological dynamic energy budget (DEB) models. MEPS 480:99-117

Sarà G, Palmeri V, Rinaldi A, Montalto V, Helmuth B (2013b) Predicting biological invasions in marine habitats through ecophysiological mechanistic models: a case study with the bivalve Brachidontes pharaonis. Divers Distrib 19(10):1235-1247

Smith WHF, Sandwell DT (1997) Global sea floor topography from satellite altimetry and ship depth soundings. Science 277(5334):1956-1962

Stachowicz JJ, Terwin JR, Whitlatch RB, Osman RW (2002) Linking climate change and biological invasions: ocean warming facilitates nonindigenous species invasions. Proc Natl Acad Sci 99(24):15497-15500

Swennen C, Leopold M, Stock M (1985) Notes on growth and behaviour of the American razor clamEnsis directus in the Wadden Sea and the predation on it by birds. Helgol Mar Res 39(3):255-261

Swets JA (1988) Measuring the accuracy of diagnostic systems. Science 240(4857):1285-1293

Syfert MM, Smith MJ, Coomes DA (2013) The effects of sampling bias and model complexity on the predictive performance of MaxEnt species distribution models. PLoS One 8(2):e55158

Tittensor DP, Baco AR, Brewin PE, Clark MR, Consalvey M, Hall-Spencer J, Rowden AA, Schlacher T, Stocks KI, Rogers AD (2009) Predicting global habitat suitability for stony corals on seamounts. J Biogeogr 36(6):1111-1128

Tulp I, Craeymeersch J, Leopold M, van Damme C, Fey F, Verdaat H (2010) The role of the invasive bivalve Ensis directus as food source for fish and birds in the Dutch coastal zone. Estuar Coast Shelf Sci 90(3):116-128

Václavík T, Meentemeyer RK (2009) Invasive species distribution modeling (iSDM): are absence data and dispersal constraints needed to predict actual distributions? Ecol Model 220(23):3248-3258

Václavík T, Meentemeyer RK (2012) Equilibrium or not? Modelling potential distribution of invasive species in different stages of invasion. Divers Distrib 18(1):73-83

Vierna J, Jensen KT, González-Tizón AM, Martínez-Lage A (2012) Population genetic analysis of Ensis directus unveils high genetic variation in the introduced range and reveals a new species from the NW Atlantic. Mar Biol 159(10):2209-2227

Von Cosel R (2009) The razor shells of the eastern Atlantic, part 2.* Pharidae II: the genus Ensis Schumacher, 1817 (Bivalvia, Solenoidea). Basteria 73(1-3):9-56

Von Cosel R, Dörjes J, Mühlenhardt-Siegel U (1982) Die amerikanische Schwertmuschel Ensis directus (Conrad) in der Deutschen Bucht: I. Zoogeographie und Taxonomie im Vergleich mit den einheimischen Schwertmuschel-Arten. Senckenbergiana Maritima 14(3-4):147-173

Wiens JJ, Graham CH (2005) Niche conservatism: integrating evolution, ecology, and conservation biology. Annu Rev Ecol Evol Syst 36:519-539

Wiens JA, Stralberg D, Jongsomjit D, Howell CA, Snyder MA (2009) Niches, models, and climate change: assessing the 
assumptions and uncertainties. Proc Natl Acad Sci 106(Supplement 2):19729-19736

Wiley E, McNyset KM, Peterson AT, Robins CR, Stewart

AM (2003) Niche modeling and geographic range predictions in the marine environment using a machine-learning algorithm. Oceanography 16(3): $120-127$ 